\title{
CONTROL OF BACTERIAL WILT OF TOMATO BY STREPTOMYCIN IN A HYDROPONIC FARM ${ }^{1}$
}

During the month of November 1953 a sudden outbreak of bacterial wilt was observed in a 2-acre tomato hydroponic farm of the Land Authority at Vega Alta, P. R. The hydroponic installation consisted of two sections each with a capacity of 26,000 gallons of nutrient solution. Each unit consisted of 30 beds, each bed holding approximately 300 plants. Symptoms of typical bacterial wilt were first observed in one bed where approximately 8 percent of the plants were affected. Several of the diseased plants were uprooted and brought to the Plant Pathology Department for bacteriological study.

From stem pieces which showed brown discoloration of vascular tissue as well as from the ooze exuded by pieces of cut stems placed in water, pure cultures of a highly motile, gram-negative bacillus were obtained. The isolated bacterium was subsequently identified as Pseudomonas solanacearum E.F.S. Because of the special conditions in a hydroponic farm. in which the infectious agent may be rapidly spread from diseased to healthy plants through the nutrient solution, rapid measures for identification and control had to be taken. Since broth cultures were available, sensitivity tests with antibiotic dises (Difco) ${ }^{2}$ were performed by seeding nutrient agar plates with 24-hour-old broth cultures.

Results of the sensitivity test showed that the bacterium was susceptible in vitro to a concentration of $1 \mu \mathrm{g}$. of streptomycin, being therefore very sensitive to the antibiotic. On this basis a recommendation was made to apply streptomycin sulfate directly to the main tank of the nutrient solution of the affected section so that a final concentration of approximately $4 \mu \mathrm{g}$. of streptomycin per milliliter would be reached. At the same time the more heavily affected plants were removed and only those showing slight wilting effects (one or two wilted leaves) were left. In a few days the slightly wilted plants recovered completely and no more cases appeared. A second dose of streptomycin was given the following week so as to insure complete recovery in the affected section.

The success of streptomycin treatment in this particular outbreak is believed to have been due to the fast action taken. The application of streptomycin directly to the tank of nutrient solution made the antibiotic

1 The observations recorded here were mude in 1953 , but had not been reported before because circumstances prohibited the completion of a larger, planned, experimental study.

${ }^{2}$ Difco Manual of Dehydrated Culture Media and Reagents, 9th ed.-Difco Laboratories, Detroit 1, Mich.

193

\section{JOURNAL OF AGRICULTURE OF UNIVERSITY OF PUTRTO RICO}

rapidly available to all the tomato plants in the hydroponic section affected by bacterial wilt. The disease was controlled in plants already showing symptoms of wilt and healthy plants were presumably protected from becoming infected via the solution. 